\title{
Comparison of Humeral Intramedullary Nail Internal Locking System and Standard External Locking System
}

\author{
Humerus İntramedüller Çivi İçten Kilitleme Sistemi ile Standart Eksternal Kilitleme \\ Sisteminin Karşılaștırılması
}

\author{
(D) Alican Barış, (D) Yusuf Öztürkmen
}

University of Health Sciences Turkey, İstanbul Training and Research Hospital, Clinic of Orthopedics and Traumatology, İstanbul, Turkey

\begin{abstract}
Introduction: This study aimed to compare the "Freehand Distal Locking (FHDL)" method, which is a standard in the distal locking stage of the humerus intramedullary nails, and the "Inside-to-Out Distal Locking (IODL)" Method, which was developed as a new nailing model.

Methods: A total of 51 patients who underwent intramedullary nailing surgery due to humeral shaft fractures in our clinic were included in the study. Trigen Humeral nail (Smith and Nephew, Memphis, USA) with FHDL was used in 24 patients, and InSafeLock Humeral nail (TST, İstanbul, Turkey) with IODL in 27 patients. The effects of these two different nailing and locking techniques used in humeral shaft fractures in terms of surgical duration, radiation exposure duration, and functional/ radiological results were evaluated.
\end{abstract}

Results: The mean follow-up period of the 51 patients (28 males and 23 females; mean age: 41.8 years) was 34.6 months (range: 9-76). According to the $A O$ classification, 24 fractures were evaluated as type A, 17 were type $B$, and 10 were type $C$. The general evaluation of all cases revealed positive correlations between the surgical and radiation exposure durations $(r=0.855 ; p<0.01)$. As the surgery duration prolonged, the ionizing radiation exposure increased. The comparison of the two groups determined a decreased surgical duration by 24.9 minute (81.6 $\mathrm{min}$ vs $106.5 \mathrm{~min}$ ) and a decreased radiation exposure duration by $28.8 \mathrm{sec}(17.7 \mathrm{sec}$ vs $41.5 \mathrm{sec})$ in the IODL case group compared to the FHDL case group $(p<0.05)$. The functional result evaluation revealed constant scorings that were satisfactory and close to each other in both groups (94.3 vs 93.3) ( $p>0.05)$. The full union was obtained in all patients except one case in the FHDL group. Symptomatic biceps tendinopathy findings were detected in four cases in the IODL group and five in the FHDL group. Local pain and sensitivity were detected in two cases in the IODL group in the form of impingement in the triceps olecranon insertion, where the distal end of the endopin is located.

Conclusion: Distal locking is the most problematic stage of humerus nailing surgeries. Adjustable external guides solve

\section{öZ}

Amaç: Bu çalıșmada humerus intramedüller çivilerinin distal kilitleme aşamasında standart kullanılan "Serbest El Distal Kilitleme" (SEDK) yöntemi ile yeni bir çivi modelinde geliștirilen "Içten Dışa Distal Kilitleme" (IDDK) yönteminin karşılaștırılması amaçlanmıştır.

Yöntemler: Kliniğimizde humerus diafiz kırı̆̆ı nedeniyle intramedüller çivi ameliyatı yapılan 51 hasta çalıșmaya dahil edildi. Bu hastaların 24'ünde SEDK yapılan Trigen Humerus çivisi (Smith ve Nephew, Memphis, ABD), 27'sinde ise IDDK yapılan InSafeLock Humerus çivisi (TST, İstanbul, Türkiye) kullanıldı. Humerus kırıklarında kullanılan bu iki farklı çivi ve kilitleme tekniğinin; ameliyat süresi, radyasyon maruziyeti süresi ve fonksiyonel/radyolojik sonuçlar üzerine etkisi incelendi.

Bulgular: Çalışmaya dahil edilen 51 hastanın (28 erkek ve 23 kadın; ortalama yaş: 41,8 yıl) takip süresi ortalama 34,6 ay (dağılım: 9-76) idi. AO sınıflamasına göre kırıkların 24'ü tip A, 17'si tip B ve 10'u tip C olarak değerlendirildi. Tüm olgular genel olarak değerlendirildiğinde ameliyat süresi ve radyasyona maruziyet süreleri arasında pozitif yönde korelasyon olduğu saptandı $(r=0,855 ; p<0,01)$. Ameliyat süresi uzadıkça ionize radyasyona maruziyetinin arttı̆̆ı görüldü. Iki grup karşılaștırıldığında; IODL olgu grubunda SEDK olgu grubuna kıyasla ameliyat süresinin 24,9 dakika (81,6 min vs $106,5 \mathrm{~min})$, radyasyona maruziyet süresinin 28,8 saniye $(17,7 \mathrm{sn}$ vs. 41,5 sn) kısaldığı tespit edildi $(p<0,05)$. Fonksiyonel sonuçlar değerlendirildiğine; her iki grupta birbirine yakın ve tatminkar Constant skorlamaları $(94,3$ vs 93,3$)$ elde edildi $(p>0,05)$. SEDK grubundaki bir olgu hariç tüm hastalarda tam kaynama elde edildi. IDDK grubundan dört olguda, SEDK grubunda ise beş olguda semptomatik biceps tendinopati bulguları görüldü. iDDK grubunda iki olguda endopinin distal uçunun bulunduğu triceps olekranon insersiosunda impingement tarzında lokal ağrı ve hassasiyet tespit edildi.

Sonuç: Distal kilitleme, humerus çivi ameliyatlarının en sorunlu așamalarındandır. Dış kılavuzlar proksimal kilitleme sorununu çözebilirken, distal kilitlemede yetersiz kalmaktadır. 
the proximal locking problem; however, they are insufficient in distal locking. Therefore, the FHDL method is more preferred in distal locking, which causes problems like prolonged surgical durations and excessive ionizing radiation exposure.

The surgical duration shortened and ionizing radiation exposure decreased at significant levels in the IODL humerus nailing with endopin. In addition, the lack of additional incisions for distal locking will avoid possible neurovascular injuries and incision-related wound complications.

Keywords: Humerus diaphysis fractures, humerus intramedullary nailing, distal locking
Bundan dolayı distal kilitlemede freehand tekniği daha çok tercih edilmektedir. Bu da ameliyat süresinin uzaması ve așırı ionize radyasyona maruziyet gibi problemlere neden olmaktadır. Endopin ile IDDK yapılan humerus çivisinde ameliyat süresinin kısaldığı ve iyoize radyasyona maruziyetin önemli ölçüde azaldığı görülmektedir. Ayrıca distal kilitleme için ek bir insizyonun gerektirmemesi, olası nörovasküler yaralanmaların ve insizyona bağlı yara komplikasyolarının önlenmesinde fayda sağlayacaktır.

Anahtar Kelimeler: Humerus diafiz kırıkları, humerus intrameduller çivileme, distal kilitleme

\section{Introduction}

Humerus diaphysis fractures account for 3-5\% of all fractures in the body, and approximately $20 \%$ of the humerus fractures $(1,2)$. Consensus on the best treatment approach for these fractures is unavailable (3). Surgical methods, such as intramedullary nailing, plaquing, or external fixation are often used in this respect in addition to non-surgical procedures like functional bracing (4). Open reduction and internal fixation with plaque/screw traditionally preferred surgical treatment methods for humerus shaft fractures. However, this method causes complications, such as radial nerve damage, fracture hematoma discharge, increased blood loss, periosteal blood flow deterioration, and postoperative infection, due to a direct fracture area exposure in open reduction $(2,4,5)$. Therefore, intramedullary nailing gained popularity as a surgical method for humerus diaphysis fractures. Many authors argued that intramedullary nailing should be the standard approach in humerus diaphysis fracture surgery $(2,6,7)$. Intramedullary nailing is a less invasive procedure that contributes more union by increasing fracture fixation stability, minimizes the risk of iatrogenic radial nerve damage, and reduces other complications based on open reduction $(6,8,9)$. The most important disadvantage of intramedullary nailing is the difficulty in placing the nail and distal locking screws. Different distal locking systems were developed; however, the "Freehand Distal Locking (FHDL") is still the most commonly used method. This method, which is based on blinded soft tissue dissection to minimize iatrogenic neurovascular injury, requires surgical expertise. In addition, it prolongs the general surgical duration and increases the ionized radiation exposure duration in the patient and the surgical team (10-12). Novel implant designs were developed to make the distal locking technique safer and overcome these problems (10).

This study aimed to clinically compare the humerus intramedullary nails in which two different distal locking techniques were used.

\section{Methods}

Necessary permissions for this retrospective study were obtained. The approval form the University of Health Sciences Turkey, İstanbul Training and Research Hospital Local Ethics Committee was obtained (approval number: 1863, date: 14.06.2019). Informed consent was obtained from all study participants. Patients who applied to our emergency department with humeral shaft fractures, who underwent antegrade intramedullary nailing surgery between January 2012 and December 2019, were included in this study. Patients with pathological fractures, vascular nerve injuries, open fractures, revision surgery cases, and are polytraumatized were excluded from the study. The gender, age, fracture type, intra- and postoperative complications, radiation exposure during surgery, and surgical duration of patients were recorded and examined. Graphics in routine clinical follow-ups were evaluated. Functional scoring of patients was made according to the latest clinical followups. Patients were divided into two groups according to the nail model used in fracture fixation. A total of 24 cases using the Trigen Humeral nail (Smith and Nephew, Memphis, USA) had FHDL technique and 27 cases using the "Inside-to-out Distal Locking (IODL)" technique had an endopin sent through InSafeLock Humeral nail (TST, İstanbul, Turkey) were included in the study.

\section{Surgical Technique}

A similar surgical technique was used in both groups until the distal locking stage of the nail. Patients in lounge-chair position under general anesthesia first underwent prophylactic antibiotherapy with $1 \mathrm{gr}$ of intravenous cefazolin. Preparations were made for necessary sterilization. Approximately $3 \mathrm{~cm}$ anterolateral incision was made toward the distal from the acromion to reach the top of the humerus. The entry point of the nail was between the tuberculum majus and sulcus intertubercularis medial, and on the posterior lateral biceps tendon. From this point, a guide K-wire and C-arm were sent to the metaphysis medulla. The nail entry point was expanded by carving as large as the diameter of the nail over the K-wire. The fracture was reduced under the C-arm control. The guide was passed through the fracture line, and the distal fracture part was advanced toward the end of its medulla. The nail size used for fixation was determined with another guidewire of the same size. Starting with the smallest reamer over the guidewire in the medulla, a carving was made to send the thickest nail possible. For proximal screw locking, the nail in an appropriate size and thickness attached to the external guide was inserted into the medulla. Then the surgery team moved on to the intramedullary locking stage of the nail. After which, proximal screw locking was made in the FHDL group, firstly over the external guide. Then, the distal screws were inserted with the FHDL technique under the scope control with mini-incision. In this technique, the distal locking hole of the nail was found with the perfect circle technique in lateral imaging and then drilled. Before leaving the 
drill from the locking hole, the procedure was checked with anteriorposterior and lateral imaging. After the screw insertion, the screw position is rechecked with lateral imaging. If the image of the circle in the monitor was closed with the screw head, the locking was considered successful. In the IODL group, the humerus distal posterior cortex in the distal end of the nail was drilled inside-out with the K-wire sent through the nail channel. Distal locking was performed with the endopin sent from the nail channel (Figure 1A). The InSafeLock humerus nail is designed to keep the proximal end of the endopin below the proximal locking screws of the nail. In this way, it allows proximal locking over the external guide (Figure 1B). After the proximal locking, the incision was closed and the surgery was terminated (Figure 1C). Patients who started exercises on the postoperative second day in both groups were discharged and called for routine follow-ups.

\section{Statistical Analysis}

The Number Cruncher Statistical System 2007 (Kaysville, Utah, USA) program was used for statistical analyses. The descriptive statistical methods (mean, standard deviation, median, frequency, ratios, minimum, and maximum) were used in analyzing the study data, as well as the Mann-Whitney $U$ test to compare the variables without normal distribution in quantitative data. The Spearman Correlation Analysis was used to evaluate the relationship among the quantitative variables. The significance level was evaluated at $p<0.05$ levels.

\section{Results}

The study included 51 patients (28 males and 23 females; mean age 41.8 years) who underwent intramedullary humerus nails. The followup time was 34.6 months on average (distribution: 9-76). According to the AO classification, 24 fractures were evaluated as type A, 17 as type $B$, and 10 as type $C$. The nail selection used in the fracture detection did not depend on any rule but was made according to the nail model supplied by our hospital purchasing unit.

The general evaluation of all cases revealed a positive correlation between the surgical and radiation exposure duration $(r=0.855 ; p<0.01)$ (Table 1). The comparison of both groups revealed a decreased surgical and radiation exposure duration at significant levels in the IODL group compared to that of the FHDL group $(p<0.05)$. The functional result evaluation revealed satisfactory and close to each other constant scores in both groups $(p>0.05)$ (Table 2$)$.

Union was achieved in all cases in the IODL group (Figure 2). Only one case had non-union in the FHDL group. The case revision surgery includes the intramedullary nails extirpation, open reduction, grafting, and plaque for fixation. The case with the union in the follow-ups was excluded from the study. In addition, symptomatic biceps tendinopathy findings were detected in four cases in the IODL group and five in the FHDL group. Soft tissue problems were not encountered in favor of impingement in the distal locking area of the FHDL group; however, local pain and sensitivity were described in two cases in the IODL group in the form of impingement in the triceps olecranon insertion, where the distal end of the endopin was located. Three patients in the IODL group and two in the FHDL group had a local infection in the shoulder incision area in the early postoperative period. In addition, local redness and mild discharge in the distal locking zone were observed in three patients in the FHDL group. All local infection findings were conservatively followed, provided with full cure.
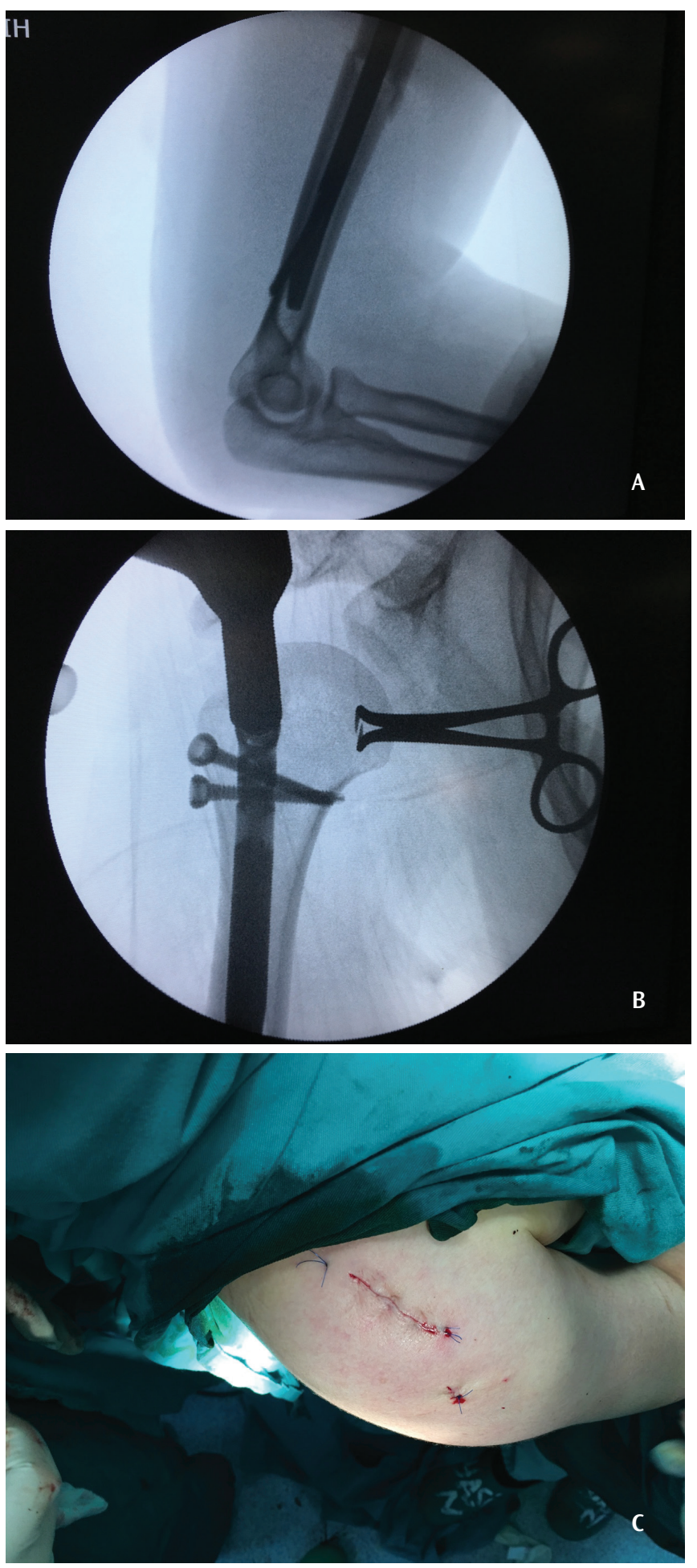

Figure 1. (A) A 22-year-old female lateral scope image after a distal lock with endopin, (B) scope image of the same case after proximal lock, (C) surgery incision image of the same case 
Table 1. Relationship between surgical and radiation exposure durations

\begin{tabular}{|l|l|l|}
\hline & \multicolumn{2}{|l}{ Surgery duration-duration to radiation exposure } \\
\hline Total & $\mathbf{r}$ & $\mathbf{p}$ \\
\hline FHDL group & 0.855 & $0.001^{* *}$ \\
\hline IODL group & 0.858 & $0.001^{* *}$ \\
\hline r: Spearman's correlation coefficient, ** $p<0.01$ & 0.875 & $0.001^{* *}$ \\
\hline
\end{tabular}

Table 2. Evaluation of surgery duration, radiation exposure duration, and functional scoring according to groups

\begin{tabular}{|c|c|c|c|c|c|}
\hline & & Total & FHDL group & IODL group & $\mathrm{p}$ \\
\hline \multirow{2}{*}{ Surgery duration (min) } & Min-max (median) & 52-184 (84) & 68-184 (98) & $52-158(74)$ & \multirow{2}{*}{$0.018^{*}$} \\
\hline & Mean $\pm S D$ & $92.91 \pm 32.52$ & $106.47 \pm 34.58$ & $81.61 \pm 26.61$ & \\
\hline Duration to radiation exposure (s) & Mean \pm SD & $28.52 \pm 17.87$ & $41.47 \pm 14.79$ & $17.72 \pm 12.22$ & $0.001^{* * *}$ \\
\hline Constant score & Min-max (median) & 80-100 (96) & $81-100(96)$ & $80-100(96)$ & 0.754 \\
\hline
\end{tabular}
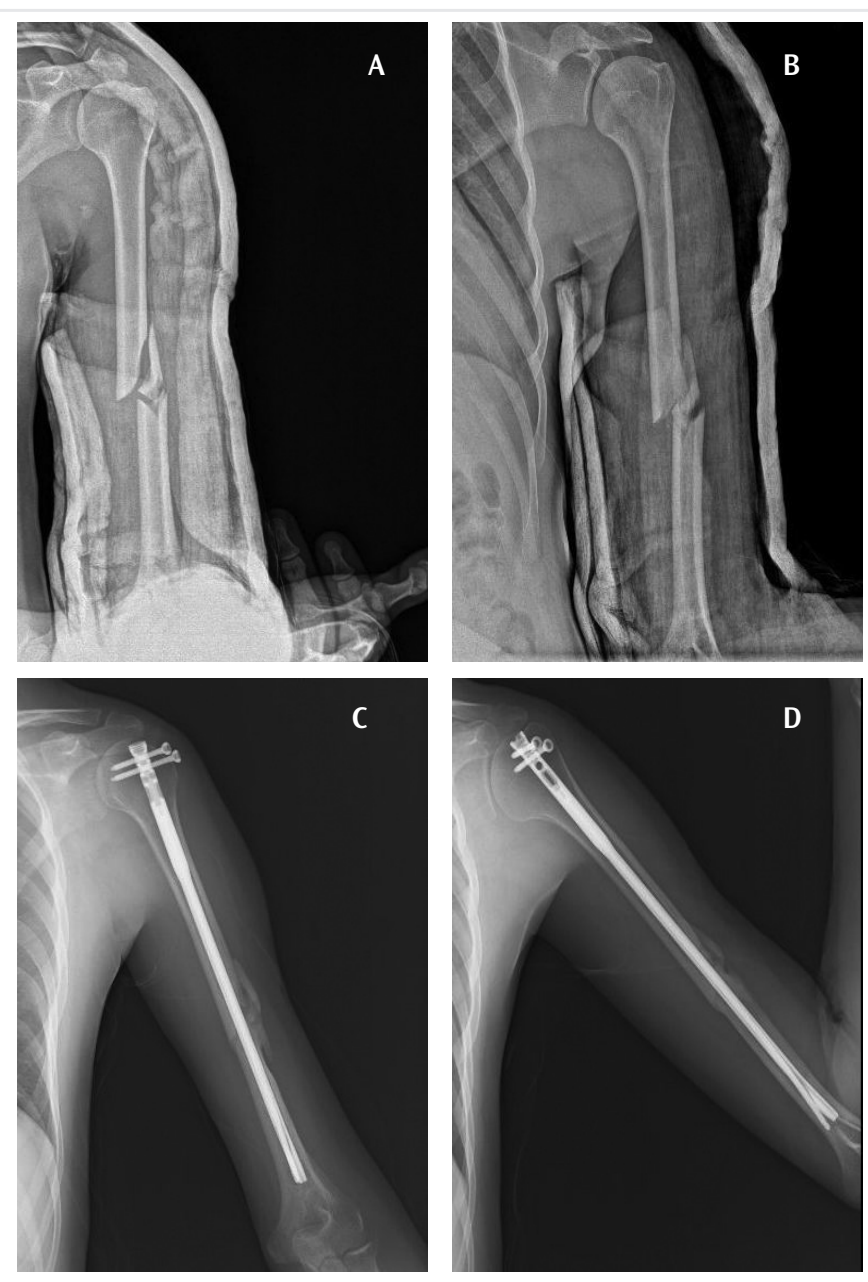

Figure 2. (A, B) Humerus diaphysis fracture preoperative bilateral X-ray image of a 32-year-old male, (C, D) bilateral X-ray image of the same case in postoperative $12^{\text {th }}$ month

\section{Discussion}

Distal screw locking is one of the most problematic stages of humerus intramedullary nail surgeries. Standard external guides attached to the intramedullary nail proximally aiming to lock the extremities outside have greatly solved the problem of locking proximal holes. However, these guides cannot bring the targeted success in locking distal holes due to the deterioration of the compliance between the nail and the external guide as proceeded toward the distal area from the proximal bone area. The nail pushed to the medullary canal is forced to bend and twist, thus, the specific tilt design changes. Therefore, the adjustment between the rigid external guide and the nail, which is forced to take the bone medulla shape, is disrupted. As a result, the drilling to find the nail holes through the external guide goes off the intended track $(2,13)$. In addition, the curved and narrowing anatomic structure of the distal humerus makes it difficult to drill the lateral cortex and frequently causes the drilling to shift from the targeted area. Moreover, the lack of the upper extremity fixation during surgery increases the probability of missing the distal nail hole by causing small rotational movements in the nail and the distal humerus fracture segment (2), causing the humerus nail to be abandoned during distal locking $(2,14,15)$. Some researchers conducted studies on whether distal locking is required or not $(14,15)$. A clinical trial compared the bipolar locking (proximal + distal) and unipolar locking (only proximal) application in the humerus nails and detected no significant differences between the two groups in terms of bone union and clinical outcomes (14). Another similar study reported radiological and functional positive results when the nail proceeded as much as possible toward the distal medulla area instead of a fixed distal locking area. The study emphasized that ideal nail size selection is important in surgery. Short nail selection would not end up with shoulder impaction, whereas long nails cause impingement in the shoulder. In addition, in the case of excessive nail impaction, iatrogenic fracture occurs, thus requiring technical skills and experience. In addition, the need for long-term immobilization was a weakness of 
this method (15). Unlike these studies, mechanical studies have proven that distal locking was required for rotational and axial stability $(16,17)$. The humerus intramedullary nailing, which is based on the principle of intramedullary area fixation without distal locking, is weaker against twisting and torsional forces compared to nailing the distal locking and emphasized that distal locking is necessary for proper fracture union and positive outcomes in functional terms (17). A mechanical study showed that this requirement is provided with the novel IODL technique by comparing the standard distal locking screw models (16). The biomechanical evaluation was not carried out in our study; however, the rotational and axial stability was provided clinically with both distal locking methods. The controls were confirmed to preserve the stability during surgeries and with the radiological/functional results in the follow-ups.

Electromagnetic-Guided Targeting (EMGT) system is often used in overcoming the distal locking problem in intramedullary nails (2,18-20). The EMGT system is effective in intramedullary nail surgeries in lower extremity fractures $(2,18)$. A meta-analysis study showed that the EMGT system shortened the surgical duration and reduced ionizing radiation exposure in the femur and tibia intramedullary nail surgeries. The study determined that the EMGT system decreased the locking time in distal screws by $4.1 \mathrm{~min}$ (7.0 vs 11.1), the radiation exposure duration by 25.3 $\sec (5.4$ vs 30.7), and surgical duration by $10 \mathrm{~min}$ (69.0 vs 79.0) compared to that of the FHDL technique. In addition, the success of the EMGT system in achieving the target was similar to that of the FHDL technique (18). The EMGT system is successful in intramedullary nailing of the lower extremity; however, its efficiency in humerus intramedullary nailing is controversial $(2,11)$. The EMGT system did not have any success superiority to FHDL system in distal locking in humerus intramedullary nails and did not make a significant difference in total surgical duration (70.0 vs 71.9) (2). However, our study observed that the surgical duration (106.5 $\mathrm{min}$ vs $81.6 \mathrm{~min}$ ); therefore, the radiation exposure duration (41.5 sec vs $17.7 \mathrm{sec}$ ) was prolonged when the FHDL technique was used. The IODL technique was applied in a newly-developed humerus nail, thus no published studies comparing it with EMGT were found in the literature review. A separate apparatus and fluoroscopic imaging are required to detect the appropriate screw size for the screw delivery in the EMGT system. However, the IODL technique uses predetermined endopin sizes according to the nail size. No fluoroscopic imaging is required to determine the endopin size. Therefore, the IODL technique is advantageous compared to the EMGT system.

These different locking methods used in humerus intramedullary nails bring with them some iatrogenic injuries. However, with the evolving nailing technologies, injuries were minimized especially in the proximal locking area $(10,21)$. The different techniques applied for the distal locking area change the rate of injury. A previous study compared two different nail models in an anatomical cadaver in terms of nerve injuries, wherein the IODL technique (InSafeLock Nail) was applied to the right humerus of seven cadavers for distal locking and the FHDL technique (Trigen nail) was applied to the left humerus. Then, the distal and proximal locking areas were dissected and examined. The proximal locking areas of the nails were similar and safe in terms of nerve injuries. In the distal region, the neurovascular structures in the nails that underwent the IODL technique were in the safe zone; however, the screws were close to the radial nerve ( $9 \mathrm{~mm}$ on average) in the nails with the FHDL technique. The lack of an extra incision in the IODL technique contributed to the neurovascular structure protection. The study reported that the surgical duration decreased in the IODL technique when surgical durations of both techniques were compared (10). Our study, parallel to this study, revealed that the IODL technique was more advantageous in terms of surgery than the FHDL technique. The clinical outcome evaluation determined that neurovascular complications were not seen in any of our patients and both nails were similarly safe.

Another possible complication of intramedullary nail surgeries of humerus fractures is iatrogenic tendon injuries. These injuries were related to the nail model, the nail entry point, and the locking method. This problem is minimized parallel to the developing nail designs.
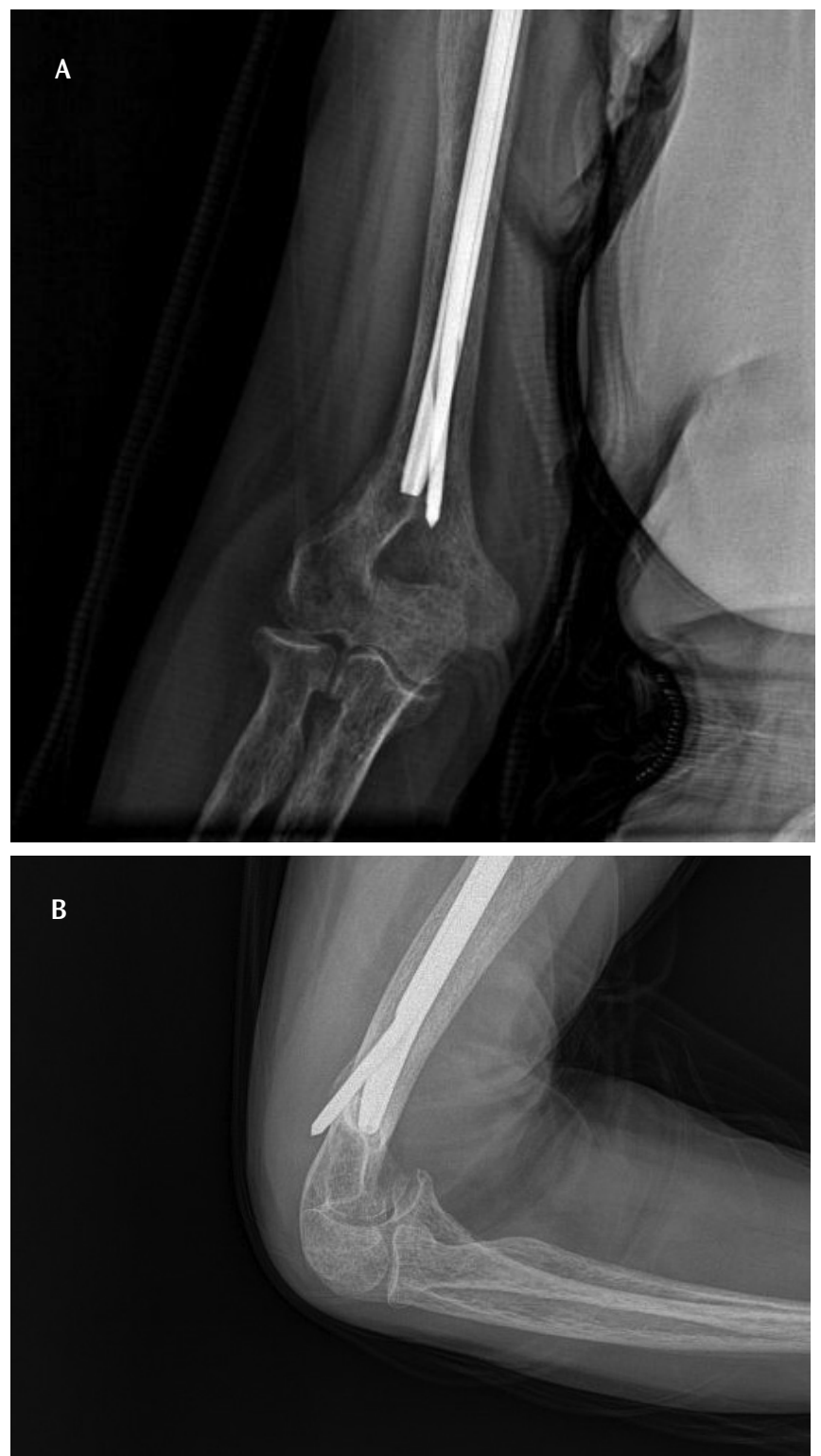

Figure 3. (A, B) bilateral X-ray image of a 54-year-old male patient describing pain in the postoperative posterior elbow 
Barıș and Öztürkmen. Distal Locking Problem in Humeral Nails

Especially the flat, small-diameter, and lock design of the thirdgeneration intramedullary humerus nails ensures that the integrity of the rotator cuff is maintained $(21,22)$. A previous study reported that the rotator cuff tendon lesions in these nails were rare and asymptomatic, with prevalence close to the general population. The same study showed that biceps long-head tendinopathy is more frequent ( $20 \%$ of the total cases) and symptomatic. Technical problems were emphasized to cause this (21). Our study not detected soft tissue problems in the distal locking area in the FHDL group; however, two cases experienced pain and sensitivity in the distal end of the endopin located in the posterior elbow area in the IODL group, which is believed to be caused by using an endopin, which is incompatible with nail length because of a technical mistake (Figure 3A, B). The proximal area examination detected symptomatic biceps tendinopathy in the nails of five cases in the FHDL group and four cases in the IODL group. The complaints regressed with conservative treatment in all patients who had symptomatic soft tissue problems. No complications were detected that require nail extirpation in any of our patients who use InSafeLock nails. The Trigen nail was extirpated in a patient who developed non-union; after removing the locking screws from the same incision areas, it was extirpated as standard other long bone nails. Any literature data on the extirpation of InSafeLock nails, which are a new design, were unavailable.

\section{Study Limitations}

The retrospective nature and the small number of cases are the main limitations of our study. In addition, the time of radiation exposure during the distal locking stage was not calculated because the duration was recorded as total time in surgical documents. Mechanical and anatomical studies are found in the literature regarding nail application by using IODL technique. However, any clinical trials on this nail in the literature review are unavailable. This present study is one of the leading clinical trials comparing the IODL technique and traditional FHDL technique.

\section{Conclusion}

The distal locking stage is the main determinant of future intramedullary nail designs. Electromagnetic locking apparatus developed in recent years, such as computer-assisted navigation systems, different nail designs, etc, show this situation. The IODL technique in the novel InSafeLock nail design is a practical solution to the distal screw locking stage of humerus intramedullary nail surgeries, which are difficult and time-consuming.

Ethics Committee Approval: The approval form the University of Health Sciences Turkey, İstanbul Training and Research Hospital Local Ethics Committee was obtained (approval number: 1863, date: 14.06.2019).

Informed Consent: Informed consent was obtained from all study participants.

Peer-review: Externally and internally peer-reviewed.

Authorship Contributions: Surgical and Medical Practices - A.B., Y.Ö.; Concept - A.B.; Design - A.B., Y.Ö.; Data Collection or Processing - A.B.; Analysis or Interpretation - A.B.; Literature Search - A.B., Y.Ö.; Writing A.B.
Conflict of Interest: No conflict of interest was declared by the authors.

Financial Disclosure: The authors declared that this study received no financial support.

\section{References}

1. Zhang R, Yin Y, Li S, Hou Z, Jin L, Zhang Y. Intramedullary nailing versus a locking compression plate for humeral shaft fracture (AO/OTA 12-A and B): A retrospective study Orthop Traumatol Surg Res 2020; 106: 1391-7.

2. Camarda L, Zini S, Butera M, Giambartino S, Mattaliano U, Raso F, et al. Electromagnetic distal targeting system does not reduce the overall operative time of the intramedullary nailing for humeral shaft fractures. J Orthop 2018; 15: 899-902.

3. Ferrara F, Biancardi E, Touloupakis G, Bibiano L, Ghirardelli S, Antonini G, et al. Residual interfragmentary gap after intramedullary nailing of fragility fractures of the humeral diaphysis: short and midterm term results. Acta Biomed 2020; 90: 432-8.

4. Updegrove GF, Mourad W, Abboud JA. Humeral shaft fractures. J Shoulder Elbow Surg 2018; 27: e87-97.

5. Wen H, Zhu S, Li C, Chen Z, Yang H, Xu Y. Antegrade intramedullary nail versus plate fixation in the treatment of humeral shaft fractures: An update metaanalysis. Medicine 2019; 98: 1-10.

6. Pautasso A, Lea S, Arpaia A, Ferrero G, Bellato E, Castoldi F. Six-year experience with antegrade intramedullary nail for the treatment of proximal and diaphyseal humeral fractures. Musculoskeletal Surg 2018; 102(Suppl1): 67-74.

7. Changulani M, Jain U, Keswani T. Comparison of the use of the humerus intramedullary nail and dynamic compression plate for the management of diaphyseal fractures of the humerus. A randomised controlled study. Int Orthop 2007; 31: 391-5.

8. Ouyang H, Xiong J, Xiang P, Cui Z, Chen L, Yu B. Plate versus intramedullary nail fixation in the treatment of humeral shaft fractures: an updated metaanalysis. J Shoulder Elbow Surg 2013; 22: 387-95.

9. Walker M, Palumbo B, Badman B, Brooks J, Van Gelderen J, Mighell M Humeral shaft fractures: A review. J Shoulder Elbow Surg 2011; 20: 833-44.

10. Tasci M, Turkmen I, Celik H, Akcal MA, Şekerci R, Keles N, et al. Insafelock humeral nail provides a safe application for proximal and distal locking screws with distal endopin-an anatomical study. Orthop Traumatol Sug Res 2019; 105: 1005-11.

11. Persiani P, Gurzi M, Moreschini O, Di Giacomo G, Villani C. Fluoroscopic freehand and electromagnetic-guided targeting system for distal locking screws of humeral intramedullary nail. Musculoskelet Surg 2017; 101: 19-23.

12. Roux A, Bronsard N, Blanchet N, de Peretti F. Can fluoroscopy radiation exposure be measured in minimally invasive trauma surgery? Orthop Traumatol Surg Res 2011; 97: 662-7.

13. Finelli CA, Ziran BH, Torini AP, Fernandes HJA, dos Reis FB. Interlocking screws placed with freehand technique and uni-planar image intensification: the "dip-stick" technique. Injury 2014; 45: \$21-5.

14. Colombi R, Chauvet T, Labattut L, Viard B, Baulot E, Martz P. Is distal locking screw necessary for intramedullary nailing in the treatment of humeral shaft fractures? A comparative cohort study. Int Orthop 2019; 43: 2151-60.

15. Tyllianakis M, Tsoumpos P, Anagnostou K, Konstantopoulou A, Panagopoulos A. Intramedullary nailing of humeral diaphyseal fractures. Is distal locking really necessary? Int J Shoulder Surg 2013; 7: 65-9.

16. Erden T, Kapicioglu M, Demirtas A, Bilsel K, Akpinar F, Kuduz H. Biomechanical comparison of humeral nails with different distal locking mechanisms: Insafelock nails versus conventional locking nails. Acta Orthop Traumatol Turc 2019; 53: 490-6 
17. Blum J, Karagül G, Sternstein W, Rommens PM. Bending and torsional stiffness in cadaver humeri fixed with a self-locking expandable or interlocking nail system: A mechanical study. J Orthop Trauma 2005; 19: 535-42.

18. Zhu Y, Chang H, Yu Y, Chen W, Liu S, Zhang Y. Meta-analysis suggests that the electromagnetic technique is better than the free-hand method for the distal locking during intramedullary nailing procedures. IntOrthop 2017; 41: 1041-8.

19. Antonini G, Stuflesser W, Crippa C, Touloupakis G. A distal-lock electromagnetic targeting device for intramedullary nailing: Suggestions and clinical experience. Chin J Traumatol 2016; 19: 358-61.
20. Han B, Shi Z, Fu Y, Ye Y, Jing J, Li J. Comparison of free-hand fluoroscopic guidance and electromagnetic navigation in distal locking of femoral intramedullary nails. Medicine 2017; 96: 1-5.

21. Muccioli C, Chelli M, Caudal A, Andreani O, Elhor H, Gauci MO, et al. Rotator cuff integrity and shoulder function after intra-medullary humerus nailing. Orthop Traumatol Surg Res 2020; 106: 17-23.

22. Dilisio MF, Nowinski RJ, Hatzidakis AM, Fehringer EV. Intramedullary nailing of the proximal humerus: Evolution, technique, and results. J Shoulder Elbow Surg 2016; 25: e130-8. 